\title{
Cx32 suppresses extrinsic apoptosis in human cervical cancer cells via the NF-kB signalling pathway
}

\author{
YONGCHANG LAI ${ }^{1,2^{*}}$, LIXIA FAN $^{1 *}$, YIFAN ZHAO $^{4 *}$, HUI GE $^{3 *}$, XUE FENG $^{3}$, \\ QIN WANG ${ }^{1}$, XIAOMIN ZHANG ${ }^{1}$, YUEXIA PENG ${ }^{1}$, XIYAN WANG ${ }^{3}$ and LIANG TAO ${ }^{1}$ \\ ${ }^{1}$ Department of Pharmacology, Zhongshan School of Medicine, Sun Yat-Sen University, Guangzhou, Guangdong 510080; \\ ${ }^{2}$ Department of Urology, Minimally Invasive Surgery Center, The First Affiliated Hospital of Guangzhou Medical University, \\ Guangzhou Urology Research Institute, Guangdong Key Laboratory of Urology, Guangzhou, Guangdong 510230; \\ ${ }^{3}$ Tumor Research Institute, Xinjiang Medical University Affiliated Tumor Hospital, Urumqi, \\ Xinjiang 830000; ${ }^{4}$ Department of Anesthesiology, Sun Yat-Sen Memorial Hospital, \\ Sun Yat-Sen University, Guangzhou, Guangdong 510120, P.R. China
}

Received March 13, 2017; Accepted June 28, 2017

DOI: 10.3892/ijo.2017.4106

\begin{abstract}
Tumour necrosis factor $\alpha(\mathrm{TNF} \alpha)$ and TNF-related apoptosis inducing ligand (TRAIL) usually trigger either survival or apoptosis signals in various cell types, and nuclear factor $\kappa \mathrm{B}(\mathrm{NF}-\kappa \mathrm{B})$ is a key factor that regulates their biological effects. Connexin 32 (Cx32) is a gap junction (GJ) protein that plays vital roles in tumourigenesis and tumour progression. Our previous study explored abnormal Cx32 expression in para-nuclear areas, exacerbated prognostic parameters and suppressed streptonigrin/cisplatin-induced apoptosis in human cervical cancer $(\mathrm{CaCx})$ cells. In this study, we investigated the role of $\mathrm{Cx} 32$ in the extrinsic apoptosis pathway of $\mathrm{CaCx}$ cells. In transgenic HeLa cells and C-33A cells, Cx32 expression was manipulated using doxycycline or Cx32 siRNA. GJ inhibitors or low density culturing was used to change the status of gap junction intracellular communication (GJIC). We found that apoptosis induced by TNF $\alpha$ and TRAIL was suppressed by Cx32 expression despite the presence or absense of GJIC. We also found that $\mathrm{Cx} 32$ upregulated the expression of nuclear NF- $\kappa \mathrm{B}$ and its downstream targets c-IAP1, MMP-2, and MMP-9 in HeLa-Cx32 and C-33A cells. Following our
\end{abstract}

Correspondence to: Professor Liang Tao, Department of Pharmacology, Zhongshan School of Medicine, Sun Yat-Sen University, 74 Zhongshan 2nd Road, Guangzhou, Guangdong 510080, P.R. China E-mail: taol@mail.sysu.edu.cn

Professor Xiyan Wang, Tumor Research Institute, Xinjiang Medical University Affiliated Tumor Hospital, 789 Suzhou Road, Urumqi, Xinjiang 830000, P.R. China

E-mail: wangxiyan2415@163.com

${ }^{*}$ Contributed equally

Key words: gap junction, Cx32, cervical cancer, TNFa, TRAIL, $\mathrm{NF}-\kappa \mathrm{B}$, extrinsic apoptosis previous study design, our clinical data showed that $\mathrm{NF}-\kappa \mathrm{B}$ and MMP-2 levels increased in human $\mathrm{CaCx}$ specimens with high Cx32 expression compared to levels in para-carcinoma of cervical specimens. SC75741 and JSH-23, NF-KB signalling pathway inhibitors, inhibited the anti-apoptotic effects of Cx32. In conclusion, Cx32 suppressed TNFa /TRAIL-induced extrinsic apoptosis by upregulating the $\mathrm{NF}-\kappa \mathrm{B}$ signalling pathway. This study demonstrates a novel mechanism for Cx32's anti-apoptotic effect and provides a reasonable explanation for the pro-tumour effect of $\mathrm{Cx} 32$ in human $\mathrm{CaCx}$ cells.

\section{Introduction}

Cervical cancer $(\mathrm{CaCx})$ progression may be related to the persistent presence of high-risk human papillomavirus (HPV) infection-derived oncoproteins E5, E6 and E7 $(1,2)$. E6 can abrogate p53-induced apoptosis by inducing p53 degradation (3). Apoptosis can be triggered by one of the two following major mechanisms: binding of death ligands to death receptors (DRs) in the extrinsic pathway or cytotoxicity that initiates the intrinsic 'mitochondrial' pathway (4). Binding ligands in the extrinsic pathway include tumour necrosis factor $\alpha(\mathrm{TNF} \alpha)$, Fas (CD95/APO1) ligand and TNF-related apoptosis inducing ligand (TRAIL). However, TNF $\alpha$ not only activates caspase- 8 in the extrinsic apoptosis pathway but also promotes tumour development via chronic inflammation. Thus, the selective inhibition of TNF-induced extrinsic apoptosis would be required for inflammation-associated tumour growth (5).

Connexins (Cxs) have gap junction (GJ) channel-dependent, hemichannel-dependent and GJ-independent pathway functions in the apoptotic process (6). Indeed, different types of Cxs may possess various functions. $\mathrm{Cx} 43$ and $\mathrm{Cx} 40$, but not $\mathrm{Cx} 37$, promote apoptosis via the transfer of pro-apoptotic signals between HeLa cells through gap junctions (7). The traditional viewpoint mainly supports GJs as a tumour suppressors (8). However, there is no consensus regarding the function of GJs composed of Cx32 in bystander effects. On the 
one hand, $\mathrm{Cx} 32$ downregulation contributes to hepatocellular carcinoma proliferation and metastasis (9), and the inhibition of GJ function or its component Cx32 significantly decreases TNF $\alpha$ hepatotoxicity (10). On the other hand, Cx32 expression also confers protective effects, which is the opposite of the effects of Cx26 in irradiated HeLa cells $(11,12)$. Aside from its GJ function, little is known regarding the non-junctional functions of $\mathrm{Cx} 32$ in $\mathrm{CaCx}$. As GJ components, Cxs also play roles outside the GJs, and the function of non-junctional Cxs appears to be contradictory in some reports. For example, in glioblastoma multiforme, $\mathrm{Cx} 43$ may be a biomarker for predicting the survival of patients with methylguanine methyl transferase-independent temozolomide resistance (13). However, Cx43 plays a pro-apoptotic role in cisplatin-induced auditory cell death in both junctional and non-junctional conditions (14). Cx26 and Cx43 may play important roles in $\mathrm{CaCx}$ carcinogenesis $(15,16)$, but the function of $\mathrm{Cx} 32$ in $\mathrm{CaCx}$ has rarely been investigated. Our previous study (17) demonstrated that, relative to controls, Cx32 was upregulated and cytoplasmically localized in $\mathrm{CaCx}$ specimens. $\mathrm{Cx} 32$ expression was correlated with an advanced FIGO staging, differentiation and increased tumour size, while non-junctional Cx32 prevented intrinsic apoptosis induced by streptonigrin in human $\mathrm{CaCx}$ cells by promoting the EGFR, ERK and STAT3 signalling pathways. As $\mathrm{CaCx}$ is highly related to HPV infections and may be related to inflammation-associated tumour growth, we investigated whether Cx32 is a key regulator of TNF-related inflammation-associated tumour growth in this study.

Because the role of $\mathrm{Cx} 32$ in the extrinsic apoptosis pathway is still unclear in $\mathrm{CaCx}$, we investigated the impact of $\mathrm{Cx} 32$ on this pathway when induced by TNF $\alpha$ or TRAIL in this study. Constitutive activation of nuclear factor $\kappa \mathrm{B}(\mathrm{NF}-\kappa \mathrm{B})$-dependent pathways is a hallmark of cancer. Abnormal NF-KB activation provides resistance to malignant cells, and the NF-KB signalling pathway is also a critical factor for apoptosis induced by TNF $\alpha$ or TRAIL. Therefore, we examined whether the NF-KB pathway was a target of $\mathrm{Cx} 32$ via treatment with various inhibitors (18).

\section{Materials and methods}

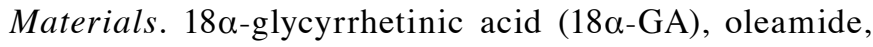
dimethyl sulfoxide (DMSO), Hoechst 33258, 2-aminoethoxydiphenyl-borate (2-APB), and anti- $\beta$-tubulin, anti- $\beta$-actin mouse IgG, anti-PCNA and secondary antibodies were acquired from Sigma-Aldrich (St. Louis, MO,USA). Anti-Cx32 antibodies were from Santa Cruz Biotechnology (Santa Cruz, CA, USA). Anti-P65 (NF-kB), histone H3, matrix metalloproteinase (MMP)-9, MMP-2, c-inhibition of apoptosis (IAP)1, $\mathrm{X}$-linked inhibitor of apoptosis (XIAP) and cleaved-caspase-3 antibodies were obtained from Cell Signaling Technology (Danvers, MA, USA). SC75741, JSH-23 and afatinib were obtained from Selleck Chemicals (Houston, TX, USA). TNF $\alpha$ reagent was from PeproTech (Rocky Hill, NJ, USA), and TRAIL was acquired from Sino Biological (Beijing, China). FITC-conjugated goat anti-rabbit secondary antibodies were from Abbkine. Hygromycin B, G418 and doxycycline (Dox) were obtained from Calbiochem (San Diego, CA, USA). Annexin V-FITC apoptosis detection kits were from Biotool (Houston, TX, USA). Cycloheximide (CHX) was obtained from DingGuo (Guang Zhou, China). Lipofectamine ${ }^{\mathrm{TM}} 2000$ and calcein-AM (acetoxymethyl ester) were acquired from Invitrogen (Carlsbad, CA, USA). All other reagents were from Sigma unless stated otherwise.

Clinical tissue samples. The clinical tissue samples were obtained from the Xinjiang Medical University-Affiliated Tumour Hospital. Cervical tissue samples were resected during surgery. The use of these clinical samples was allowed by the ethics committee of Xinjiang Medical University Affiliated Tumour Hospital.

Cell lines and cell cultures. Human $\mathrm{CaCx}$ cell lines (C-33A cell line) were purchased from the American Type Culture Collection (Manassas, VA, USA). As previously described and characterized (19), another stable Cx32-transfected HeLa cell line (HeLa-Cx32) was under the control of a bidirectional tetracycline-inducible promoter. In these cells, Cx32 expression was induced by doxycycline $(1 \mu \mathrm{g} / \mathrm{ml})$ exposure for $\sim 48 \mathrm{~h}$. The positive cells were screened with $100 \mu \mathrm{g} / \mathrm{ml} \mathrm{G} 418$ sulfate and $200 \mu \mathrm{g} / \mathrm{ml}$ hygromycin B in DMEM supplemented with $10 \%$ foetal bovine serum (FBS). C-33A cells were grown in MEM supplemented with $10 \% \mathrm{FBS}$, antibiotics and glutamine. Low-density culturing was adopted to study the non-junctional function of $\mathrm{Cx} 32$ in apoptosis. The cells were seeded in wide dishes $(150 \mathrm{~mm})$, which provided enough distance among cells such that adjacent cells were prevented from forming GJs.

GJ functional assay. Gap junction intracellular communication (GJIC) function was assessed with a 'parachute' dye-coupling assay as described by Goldberg et al (20). After cells were cultured to confluence in 12 -well plates, $5 \mu \mathrm{M}$ calcein-AM was added to donor cells for $30 \mathrm{~min}$ at $37^{\circ} \mathrm{C}$. Then, the cells were rinsed, trypsinized and seeded onto the receiver cells at a 1:150 donor/receiver ratio. Donor cells can be observed due to calcein-AM. If GJIC function is normal, calcein-AM from donor cells can be intracellularly transferred into the receiver cells. Both the donor cells and the monolayer of receiver cells were incubated for $4 \mathrm{~h}$ at $37^{\circ} \mathrm{C}$. Then, the average amount of receiver cells containing calcein-AM per donor cell was observed with a fluorescence microscope (Olympus IX71, Tokyo, Japan). The level of GJIC was measured based on the average amount of dye in the receiver cells.

Apoptosis assay. Briefly, $\sim 1-2 \times 10^{5}$ cells per well were seeded in 6 -well plates. Before adding the apoptosis-inducing reagent to the cells, HeLa-Cx32 or C-33A cells were divided into several groups (HeLa-Cx32 were incubated with or without doxycycline for $48 \mathrm{~h}$ and C-33A cells were treated with Cx32 siRNA or non-specific siRNA for $48 \mathrm{~h}$ ). HeLa-Cx32 cells were incubated with TNFa $(100 \mathrm{ng} / \mathrm{ml})$ or TRAIL $(20 \mathrm{ng} / \mathrm{ml})$ for $24 \mathrm{~h}$, while the C-33A cells were incubated with TNF $\alpha$ $(100 \mathrm{ng} / \mathrm{ml})$ plus $\mathrm{CHX}(1 \mu \mathrm{g} / \mathrm{ml})$. After the cells were washed twice with PBS, they were trypsinized and harvested. Next, the cells were centrifuged and resuspended in binding buffer. After the cells were stained with Annexin V-FITC and propidium iodide (PI) for $15 \mathrm{~min}$ at room temperature in the dark, the samples were swiftly analysed in a flow cytometer. The early or late apoptosis rate was used for the analysis in Expo32 software. 
CX32 siRNA interference experiments. After the cells had grown to $30-50 \%$ confluence, non-specific siRNA (negative control) or the Cx32 siRNA (50 nM, Ribbon, Guangzhou, China) and Lipofectamine ${ }^{\mathrm{TM}} 2000$ were added together and mixed. Then, the mixture was added to the cells in each well according to the manufacturer's protocol. After the cells were incubated with the siRNAs for $48 \mathrm{~h}$, TNF $\alpha$ (TNF $\alpha+\mathrm{CHX}$ for $\mathrm{C}-33 \mathrm{~A}$ cells) was added to induce apoptosis.

The sequences of the synthetic Cx32 siRNAs are as follows: siCx32_1, 5'-CCGGCATTCTACTGCCATT-3'; siCx32_2,5'-GGCTCACCAGCAACACATA-3'; and siCx32_3, 5'-GCAACAGCGTTTGCTATGA-3'. Among them, the inhibitory effects of siCx32_3 were the best, and it was chosen for use in the remaining experiments.

Cell viability measurement. Cells were plated in 96-well plates and treated with drugs at various concentrations for $24 \mathrm{~h}$. Cell Counting Kit-8 (CCK8) reagent was added to cells and allowed to react for a 3-4 h reaction, and the optical density was measured at a wavelength of $450 \mathrm{~nm}$ using a microplate reader (Bio-Tek Instruments). In a second method, 3-(4,5-dimethylthiazol-2-yl)-2,5-diphenyltetrazolium bromide (MTT) was added to cells for a 3-4-h reaction, and DMSO was used to dissolve the sediment. The optical density was measured at a wavelength of $490 \mathrm{~nm}$ for the MTT method. The normalized cell survival rate was measured from the optical density based on the CCK-8 and/or MTT results.

Western blot analysis. Cell plates were placed on ice after tissue or cells were washed three times with PBS. Tissues or cells were lysed in lysis buffer $[150 \mathrm{mM} \mathrm{NaCl}, 1 \mathrm{mM}$ EGTA, $1 \mathrm{mM}$ EDTA, $1 \mathrm{mM} \mathrm{Na} \mathrm{VO}_{4}, 2.5 \mathrm{mM}$ sodium pyrophosphate, $1 \%$ Triton X-100, $1 \mathrm{mM} \beta$-glycerophosphate, $20 \mathrm{mM}$ Tris- $\mathrm{HCl}(\mathrm{pH} 7.4)$ and protease inhibitors $(1: 1,000)]$ for $\geq 30 \mathrm{~min}$. After scratching, collection and ultrasonication, the lysates were centrifuged at $12,000 \mathrm{rcf}$ for $30 \mathrm{~min}$ at $4^{\circ} \mathrm{C}$, and the supernatants were collected. Proteins concentrations were measured with a BCA protein assay kit (Thermo Fisher, MA, USA). Nucleoproteins were collected using nuclear and cytoplasmic extraction reagents (Thermo Scientific) following the manufacturer's instructions (21). The same amount of each sample $(20 \mu \mathrm{g})$ was separated via SDS-PAGE and transferred to a nitrocellulose membrane. Before antibody blotting, $5 \%$ milk was used to block the membranes for $1 \mathrm{~h}$. Monoclonal antibodies including those for $\mathrm{Cx} 32$ (1:1,000), P65 (1:1,000), histone H3 (1:1,000), MMP-9 (1:1,000), MMP-2 (1:1,000), c-IAP1 $(1: 1,000)$, XIAP $(1: 1,000)$, cleaved-caspase-3 $(1: 1,000), \beta$-actin $(1: 10,000)$ and $\beta$-tubulin $(1: 10,000)$, were incubated with the membrane overnight at $4^{\circ} \mathrm{C}$. The next day, the membranes were incubated with HRP-conjugated secondary antibodies at room temperature for 1-2 h. After being washed with TBST, immunopositive bands in the membrane were detected and visualized with Western Lightning chemiluminescence reagents (Thermo Fisher). ImageJ software was used to analyse the western blotting band density data. The ratio of the target protein to the respective loading control (e.g., tubulin) was calculated, and the mean of the ratios from the control bands were normalized as ' 100 '.
Statistical analysis. All of the experiments had a minimum of three replicates. The data represent the mean \pm standard error (SE) and were analysed using SPSS 16.0 software. Statistical significance $(\mathrm{P}<0.05)$ was determined via a one-way ANOVA ( $>2$ groups) or Student's t-test ( 2 groups). Non-parametric data were analysed using two independent sample tests. Pearson's correlation analysis was used to analyzed the correlation between $\mathrm{Cx} 32$ and $\mathrm{NF}-\kappa \mathrm{B}$ expression and GraphPad Prism 6.0 software was used to create the histograms and scatter plots. In the figures, asterisk (*) represents $\mathrm{P}<0.05$ compared to the corresponding group.

\section{Results}

Overexpression of Cx32 suppressed the extrinsic apoptosis of HeLa cells regardless of whether GJ function was inhibited. Similar to the research methods used for studying the role of Cx32 in endogenous apoptosis, we first used HeLa-Cx32 cells in which the expression of Cx32 could be controlled by Dox to investigate the function of $\mathrm{Cx} 32$ in exogenous apoptosis. We detected the expression of Cx32 after HeLa-Cx32 or HeLa wild-type cells were incubated with Dox. The results showed that Dox could induce Cx32 expression in HeLa-Cx32 cells but not in HeLa wild-type cells (Fig. 1A). Reports have shown that 2-APB, 18 $\alpha$-GA and oleamide can effectively inhibit GJIC (22). According to our previous study, 2-APB, 18 $\alpha$-GA and oleamide were used as GJ inhibitors in our experiments $(23,24)$. To eliminate the interference of tool drugs on apoptosis and help choose a suitable working concentration, we detected the survival rate of cells using CCK-8 and MTT assays. Based on the results, we used inhibitors at the following concentrations which showed no significant cytotoxicity: $18 \alpha-\mathrm{GA}(10 \mu \mathrm{M})$, oleamide $(25 \mu \mathrm{M}), \mathrm{SC} 75741(1 \mu \mathrm{M})$ and JSH-23 $(2 \mu \mathrm{M})$ (Figs. 1B and 4A). We confirmed in our parachute assay that Dox could enhance GJ function, but that 2-APB, 18 $\alpha$-GA and oleamide were able to inhibit it (Fig. 1C).

Following treatment with TNF $\alpha$ or TRAIL, the early apoptosis rate of HeLa-Cx32 cells in the different groups was analysed. In the subsequent experiment, HeLa-Cx32 cells were divided into the following groups, with the total culture time of each group being equal: control group (incubated with solvent), Dox group (incubated with Dox for $48 \mathrm{~h}$ ), TNF $\alpha$ group (treated with TNF $\alpha$ for $24 \mathrm{~h}$ ), Dox+TNF $\alpha$ group (cells were incubated with Dox for $48 \mathrm{~h}$ and treated with TNF $\alpha$ for another $24 \mathrm{~h}$ ); TNF $\alpha+18 \alpha-\mathrm{GA}$ group (18 $\alpha$-GA was added $2 \mathrm{~h}$ before treatment with $\mathrm{TNF} \alpha$ ); and Dox+TNF $\alpha+18 \alpha-\mathrm{GA}$ group (incubated with Dox for $48 \mathrm{~h}$ and $18 \alpha-G A$ was then added $2 \mathrm{~h}$ before treatment with TNF $\alpha$ for another $24 \mathrm{~h}$ ). The incubation times for the other GJ inhibitors, such as 2-APB and oleamide, were identical to that used for $18 \alpha-\mathrm{GA}$. The division of the TRAIL groups was similar to that of the TNF $\alpha$ group.

In Fig. 1D, the HeLa-Cx32 cells were divided into 4 groups: the control group, Dox group, $\mathrm{TNF} \alpha$ group, and Dox+TNF $\alpha$ group. The result showed that the apoptosis rate of HeLa-Cx32 cells in the TNF $\alpha$ group was much higher than in the other groups (Fig. 1D). To confirm that $\mathrm{Cx} 32$ function was related with GJIC in this instance, low-density culturing or GJ inhibitors, such as 2-APB and 18 $\alpha$-GA, were used (Fig. 1E and F). 2 -APB or $18 \alpha-$ GA was added to inhibit GJs before TNF $\alpha$ was added to the cells. The results showed that the anti-apoptosis 
$\mathrm{A}_{\text {HeLa cells }}$

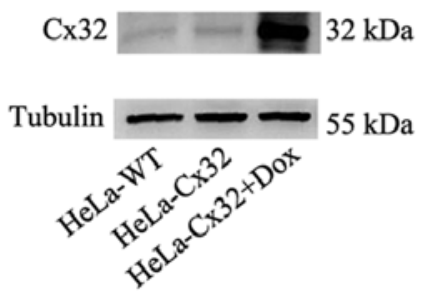

$\mathrm{D}$

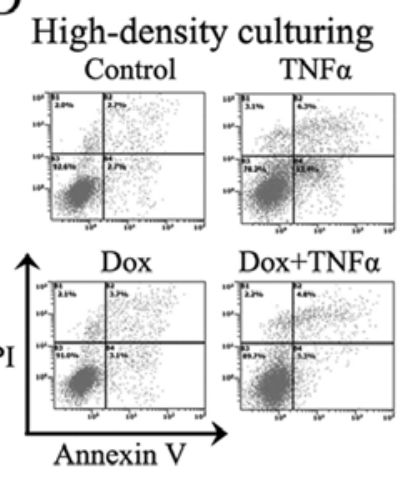

F Low-density culturing

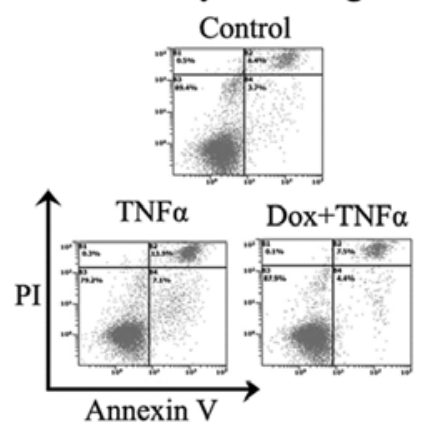

$\mathrm{B}$

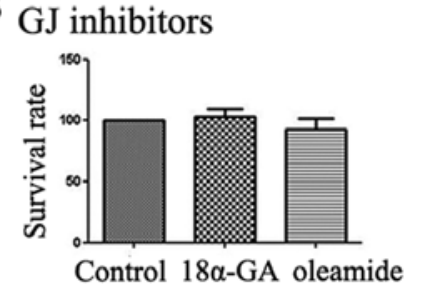

C Parachute assay

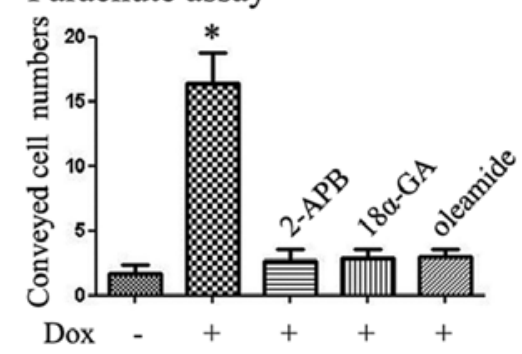

$\mathrm{E}$

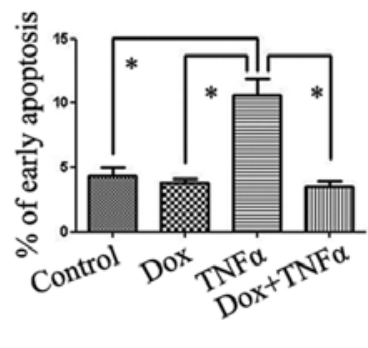

High-density culturing (GJ inhibitors)

TNF $\alpha+18 \alpha-G A$ Dox + TNF $\alpha+18 \alpha-G A$
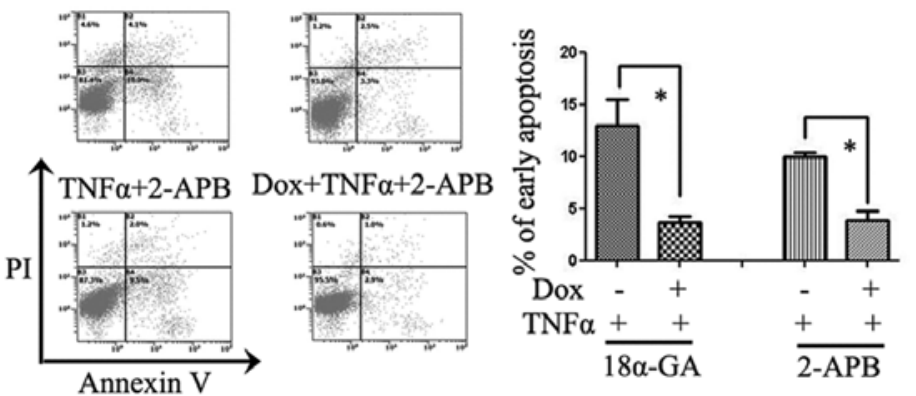

G High-density culturing (TRAIL)
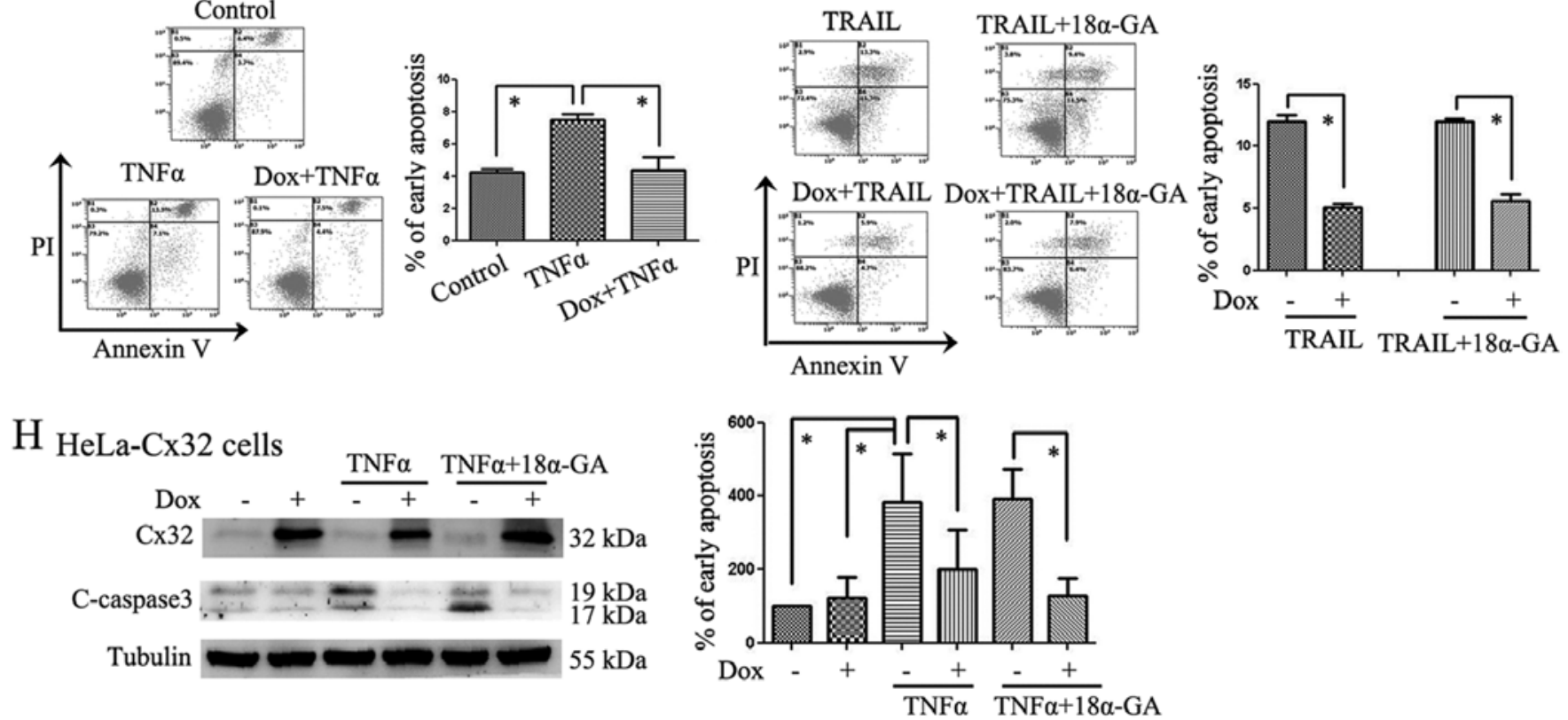

Figure 1. Cx32 expression was controlled in HeLa-Cx32 cells and its impact on apoptosis induced by TNF $\alpha$ or TRAIL was detected. (A) Cx32 expression was induced in wild-type HeLa cells (HeLa-WT) or HeLa-Cx32 cells after 48-h Dox treatment (n=3). (B) CCK-8 assay results showed that $18 \alpha$-GA $(10 \mu \mathrm{M})$ and oleamide $(25 \mu \mathrm{M})$ displayed no significant cytotoxicity to cells $(\mathrm{n}=5)$. (C) A parachute dye was used in HeLa-Cx32 cells, and Dox was used to induce Cx32 expression. The results showed that GJs were inhibited by $2-\mathrm{APB}, 18 \alpha-\mathrm{GA}$ and oleamide $(\mathrm{n}=3)$. (D) Under high-density culture conditions, $\mathrm{Cx} 32$ overexpression suppressed TNF $\alpha$-induced apoptosis $(n=4)$. (E) GJs were inhibited by 2-APB or 18 $\alpha$-GA, and these GJ inhibitors did not change the Cx32 anti-apoptotic functions $(n=3-4)$. (F) Low-density culturing showed that the Cx32 anti-apoptotic functions were still present without GJ formation (n=4). (G) Aside from TNF $\alpha$, TRAIL ( $20 \mathrm{ng} / \mathrm{ml}$ ) was used to induce apoptosis. High Cx32 expression induced by Dox inhibited the apoptosis induced by TRAIL (n=3). (H) HeLa-Cx32 cells were divided into 6 groups: control group, Dox group, TNF $\alpha$ group, Dox+TNF $\alpha$ group, TNF $\alpha+18 \alpha-G A$ group, and Dox+TNF $\alpha+18 \alpha-G A$ group. Expression of cleaved-caspase-3, an executor of apoptosis, was detected via western blotting. The results were consistent with apoptosis detection via flow cytometry with Annexin V-FITC $(\mathrm{n}=3)$. ${ }^{*} \mathrm{P}<0.05$ with respect to the control or corresponding group.

function of Cx32 was present even when 2-APB or 18 $\alpha$-GA was added (Fig. 1E). An additional method (low-density culturing) was used to ensure that the distance among cells was great enough so that they could not form GJs. In these low density cultures, Cx32 prevented apoptosis induced by TNF $\alpha$ (Fig. 1F), which was consistent with the GJ inhibitor results (Fig. 1E). Aside from TNF $\alpha$, we also utilized a stronger apoptosis inducer, TRAIL, when repeating the experiment, and the results were similar to those obtained for TNF $\alpha$ (Fig. 1G). Low-density culturing and GJ inhibitors such as 2-APB and 18 $\alpha$-GA did 


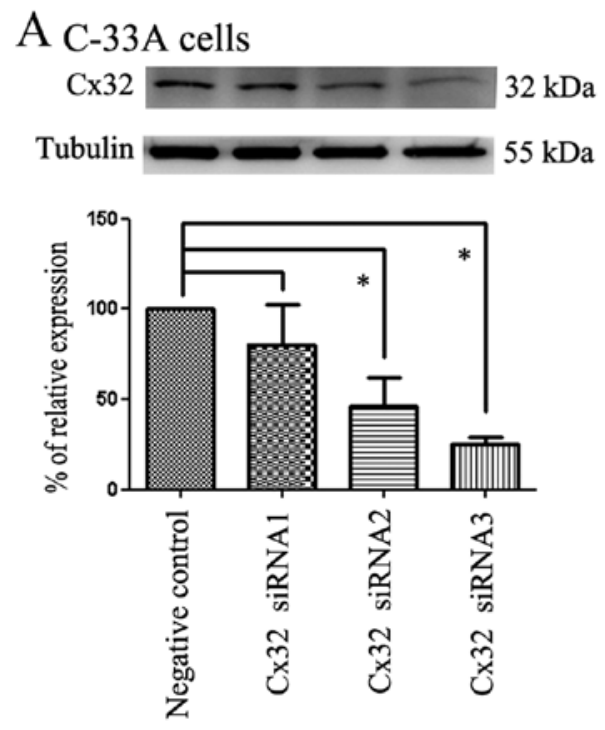
$\mathrm{B}_{\mathrm{C}-33 \mathrm{~A} \text { cells }}$ exposure of 18 $\alpha$-GA before apoptosis induction
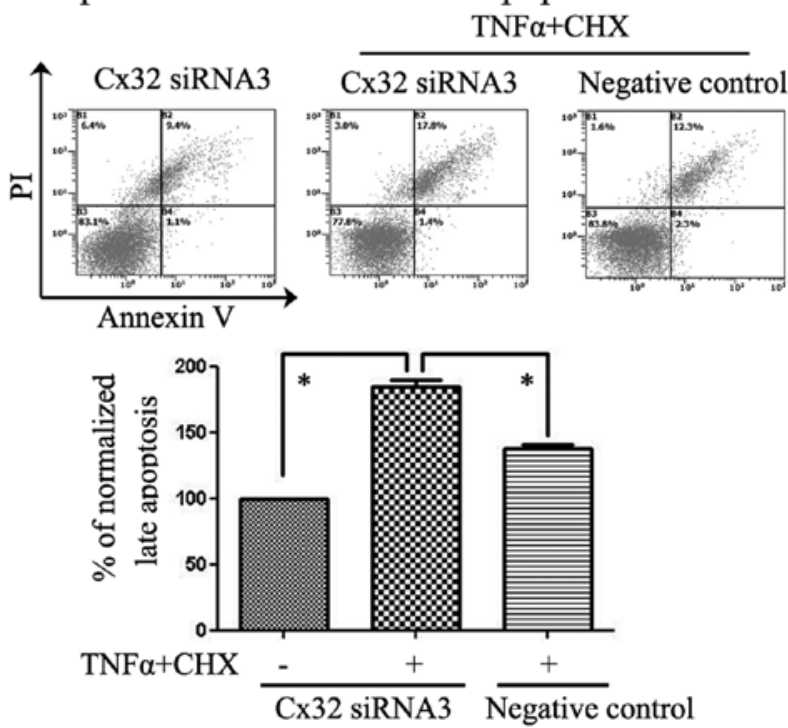

Figure 2. In C33A cells, Cx32 siRNAs were used and the non-junctional function of Cx32 in apoptosis induced by TNF $\alpha+C H X$ was dectected. (A) Non-specific siRNA was used as a negative control (NC), and three Cx32 siRNAs (S1, S2 and S3) were used to knock down Cx32 expression. S2 and S3 were both efficient, and $\mathrm{S} 3$ was chosen for further experiments (n=3). (B) After using Cx32 siRNA3 to knock down Cx32 expression, all groups were incubated with 18 $\alpha$-GA and some groups were incubated with $\mathrm{TNF} \alpha+\mathrm{CHX}$ to induce apoptosis in C33A cells. Consistent with the results from the HeLa-Cx32 experiments, the apoptosis rates (normalized) in the $\mathrm{Cx} 32$ knock down groups were much higher than in the non-specific siRNA groups after cotreatment with $\mathrm{TNF} \alpha+\mathrm{CHX}\left(\mathrm{n}=3\right.$ ). ${ }^{*} \mathrm{P}<0.05$ with respect to the control or corresponding group.

not change the anti-apoptotic functions of $\mathrm{Cx} 32$, indicating that the anti-apoptosis effect of Cx32 may not be related to GJIC. To further explore the extent of apoptosis, we also used western blotting to detect the expression of cleaved-caspase-3, which is an executioner caspase in apoptosis. HeLa-Cx32 cells were divided into the following 6 groups: control group, Dox group, TNF $\alpha$ group, Dox+TNF $\alpha$ group, TNF $\alpha+18 \alpha-G A$ group, and Dox + TNF $\alpha+18 \alpha-G A$ group. The results showed that the changes in cleaved-caspase-3 expression levels were consistent with the extent of apoptosis detected via flow cytometry using Annexin V-FITC (Fig. 1H). After a 48-h incubation with Dox, Cx32 expression was induced, and apoptosis rates were lower in the high-Cx32-expression groups.

siRNA knockdown of endogenous Cx32 expression in C-33A cells reduced the anti-apoptotic effect of $C x 32$. We also used C-33A cells as a model to further explore the role of $\mathrm{Cx} 32$ in apoptosis via negative regulation. According to our results, C-33A cells natively expressed Cx32; thus, we chose these cells for the Cx32 interference experiment. In our study, non-specific siRNAs were used as a negative control (NC) and three Cx32 siRNAs (S1, S2 and S3) were used to knock down $\mathrm{Cx} 32$ expression. S2 and S3 were the most efficient, and the $\mathrm{S} 3$ fraction was therefore used in our further experiments (Fig. 2A). As the apoptosis-inducing ability of $\mathrm{TNF} \alpha$ is limited based on our experimental results, we decided to use $\mathrm{TNF} \alpha(50 \mathrm{ng} / \mathrm{ml})$ and $\mathrm{CHX}(1 \mu \mathrm{g} / \mathrm{ml})$ in combination to induce apoptosis in C-33A cells, which has been demonstrated in previous reports (25). After using Cx32 siRNA3 to knock down Cx32 expression in C-33A cells, all of the groups were incubated with $18 \alpha-\mathrm{GA}$, and some of the groups were incubated with $\mathrm{TNF} \alpha$ plus $\mathrm{CHX}$ to induce apoptosis. Consistent with the results from the HeLa-Cx32 experiments, the apoptosis rates in the Cx32 knockdown groups were much higher than those in the non-specific siRNA groups after cotreatment with $\mathrm{TNF} \alpha$ plus CHX (Fig. 2B).

Cx32 expression upregulates $N F-\kappa B$ and activates its downstream effectors MMPs, $c$-IAPl and XIAP. Our previous study showed that $\mathrm{Cx} 32$ expression was obviously higher in $\mathrm{CaCx}$ clinical tissue samples than in normal samples. Because $\mathrm{NF}-\kappa \mathrm{B}$ acts as an important factor in the extrinsic apoptosis pathway, we examined the expression of NF- $\mathrm{B}$ and MMP-2 in $\mathrm{CaCx}$ clinical tissue samples to determine the effects of $\mathrm{Cx} 32$ on the $\mathrm{NF}-\kappa \mathrm{B}$ signalling pathway. Metalloproteases (MMPs) and c-IAP1 are downstream in the NF- $\kappa \mathrm{B}$ signalling pathway. In total, 15 samples were used to detect NF- $\mathrm{NB}$ and MMP-2 expression. Some of the samples were from $\mathrm{CaCx}$ tissue with high $\mathrm{Cx} 32$ expression, and others were from para- $\mathrm{CaCx}$ tissue with low $\mathrm{Cx} 32$ expression. Under these circumstances, we found that $\mathrm{NF}-\kappa \mathrm{B}$ and MMP-2 expression was obviously higher in $\mathrm{CaCx}$ samples than in para-CaCx samples (Fig. 3A).

Based on the variation in NF- $\kappa \mathrm{B}$ and MMP-2 levels in human cervical samples, we investigated the expression of $\mathrm{Cx} 32, \mathrm{NF}-\kappa \mathrm{B}$ and its target proteins in $\mathrm{CaCx}$ samples. Nucleoproteins and cytoplasm proteins from $15 \mathrm{CaCx}$ tissue samples were collected and then the expression of $\mathrm{NF}-\kappa \mathrm{B}, \mathrm{Cx} 32$, XIAP and c-IAP1 were detected by western blotting. The results showed that $\mathrm{Cx} 32$ expression was correlated with expression of $\mathrm{NF}-\kappa \mathrm{B}(\mathrm{r}=0.517, \mathrm{P}=0.049)$ and the variation tendency of XIAP and c-IAP1 coincided with $\mathrm{NF}-\kappa \mathrm{B}$ variation (Fig. $3 \mathrm{~B}$ ). Then we continued to explore 


\section{A Human cervix tissue}
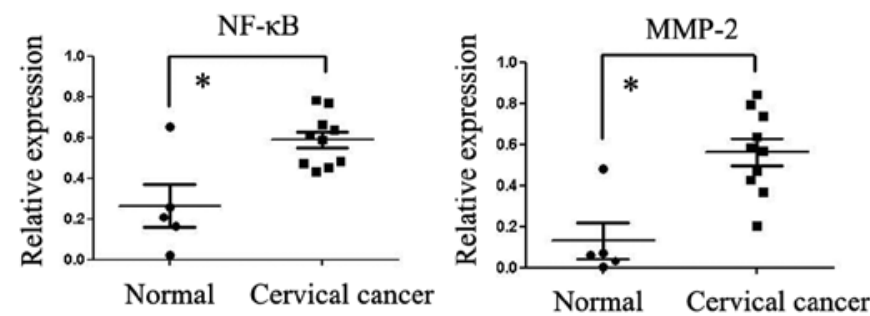

\begin{tabular}{ll|l|l|} 
& Normal & Cervical cancer \\
MMP-2 & &
\end{tabular} $2 \mathrm{kDa}$

NF-kB(P65) ーーー - -

$\beta$-actin

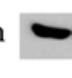

C C-33A cells

Total fraction

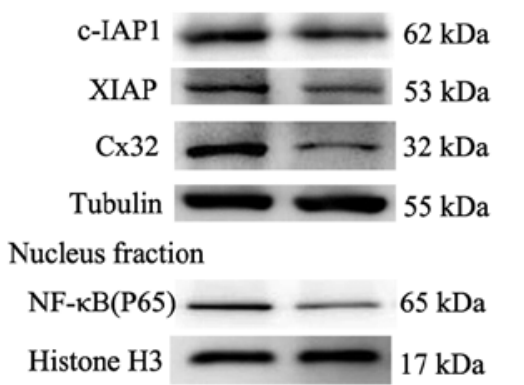

B Cervical cancer tissue

Nucleus fraction

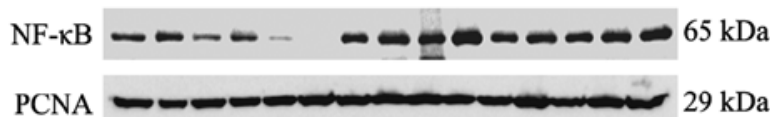

Cytoplasm fraction

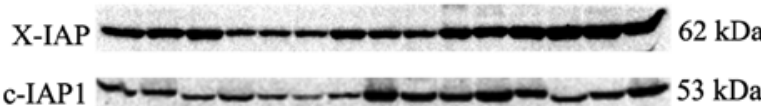

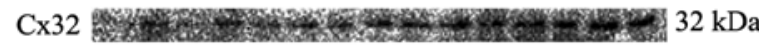
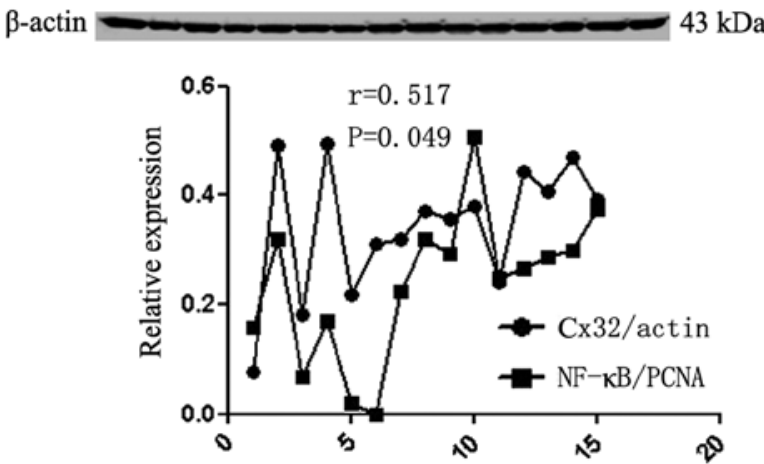

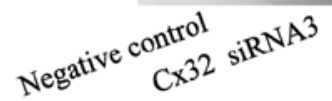

D HeLa-Cx32 cells

Control Dox

c-IAP1 $62 \mathrm{kDa}$

MMP-2

$72 \mathrm{kDa}$

$\mathrm{Cx} 32=32 \mathrm{kDa}$

Tubulin $55 \mathrm{kDa}$

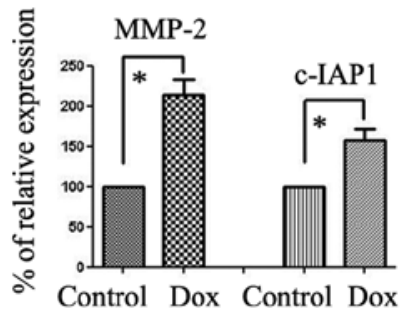

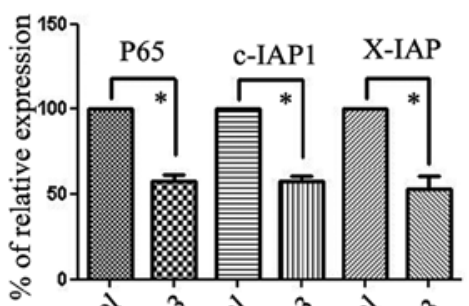

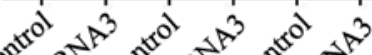

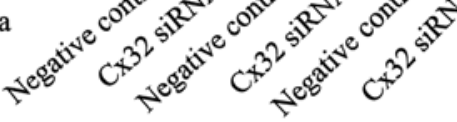

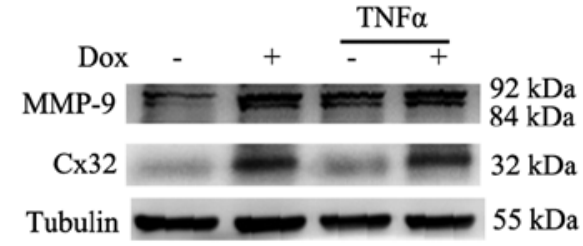

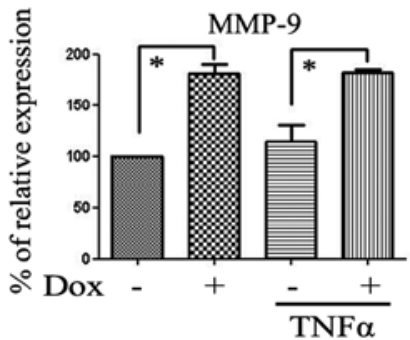

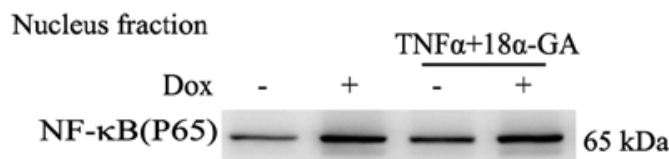

Histone $\mathrm{H} 3 \longrightarrow 17 \mathrm{kDa}$

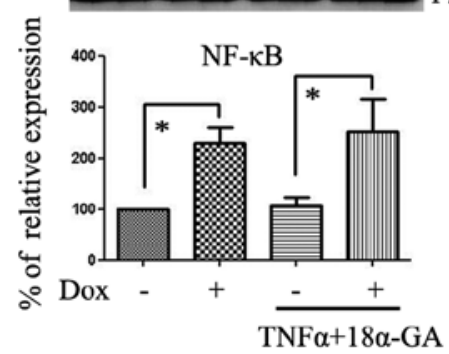

Figure 3. Cx32 affects MMP-2, MMP-9, c-IAP1 and nuclear NF-кB expression in cervical cancer cells. (A) NF- $\mathrm{KB}$ and MMP-2 expression in clinical CaCx samples was tested via western blotting. Fifteen samples were used to detect the expression of NF- $\mathrm{KB}$ and MMP-2. Some of the samples were from CaCx tissue with high $\mathrm{Cx} 32$ expression, and others were from para-CaCx tissue with low $\mathrm{Cx} 32$ expression. (B) In fifteen cases of $\mathrm{CaCx}$, $\mathrm{Cx} 32$ expression was correlated with expression of NF- $\mathrm{KB}(\mathrm{r}=0.517, \mathrm{P}=0.049)$ and the variation tendency of XIAP and c-IAP1 coincided with NF- $\mathrm{kB}$ variation. (C) After Cx32 knockdown by Cx32 siRNA3, nuclear P65 and total c-IAP1 and XIAP expression was decreased in C33A cells (n=3). (D) Cx32 regulated the expression of P65 (NF- $\mathrm{kB}$ ) in the nucleus of HeLa-Cx32 cells and regulated total MMP-9, MMP-2 and c-IAP1 expression in HeLa-Cx32 cells ( $\mathrm{n}=3$ ). ${ }^{*} \mathrm{P}<0.05$ with respect to the control or corresponding group.

the Cx32 and NF- $\mathrm{KB}$ expression in vitro. After Cx32 expression was reduced by Cx32 siRNA3, the expression of P65 in the nucleus and total XIAP and c-IAP1 expression in C-33A cells also decreased (Fig. 3C). Consistent with the results in the $\mathrm{C}-33 \mathrm{~A}$ cells, our results showed that $\mathrm{Cx} 32$ not only regulated the expression of P65 (NF- $\mathrm{kB})$ in the nucleus of HeLa-Cx32 cells but also regulated total MMP-9, MMP-2 and c-IAP1 expression in HeLa-Cx32 cells (Fig. 3D). Similar 
A NF-kB inhibitors

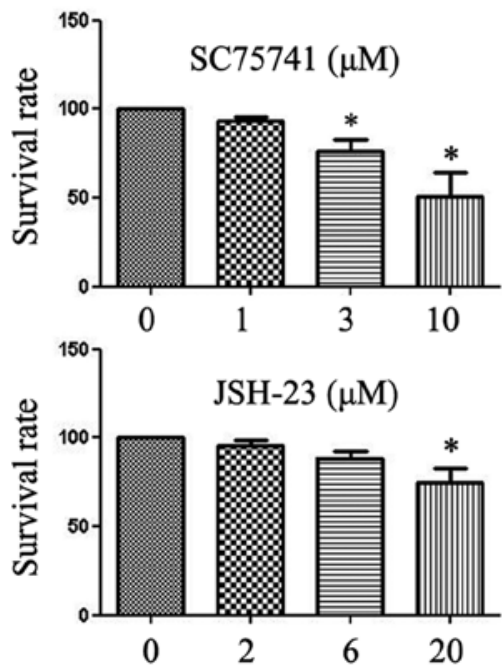

\section{$\mathrm{C}_{\mathrm{HeLa}-\mathrm{Cx} 32 \text { cells }}$}

Esposure of TRAIL+oleamide

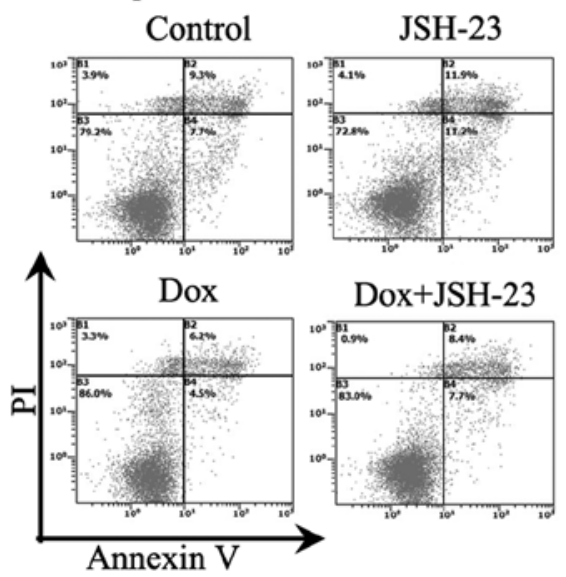

B HeLa-Cx32 cells

esposure of $18 \alpha-\mathrm{GA}+\mathrm{TNF} \alpha$

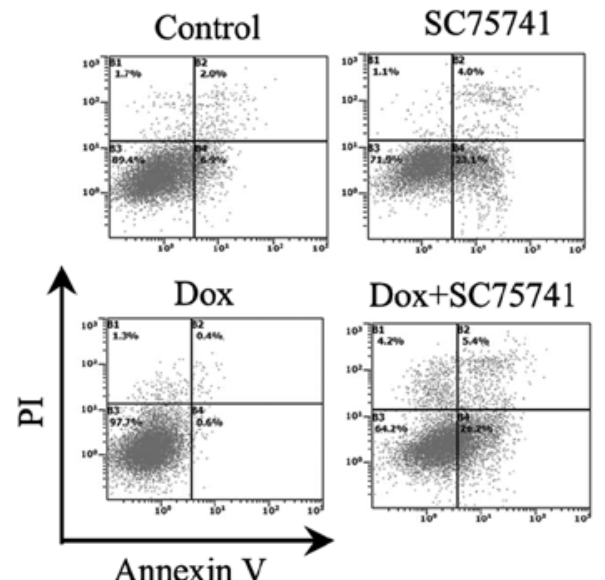

Esposure of TNF $\alpha+18 \alpha-\mathrm{GA}$

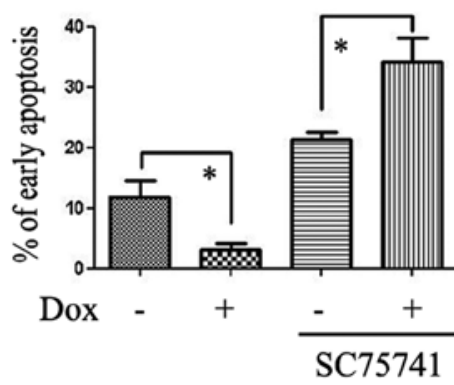

D
Esposure of TRAIL+oleamide

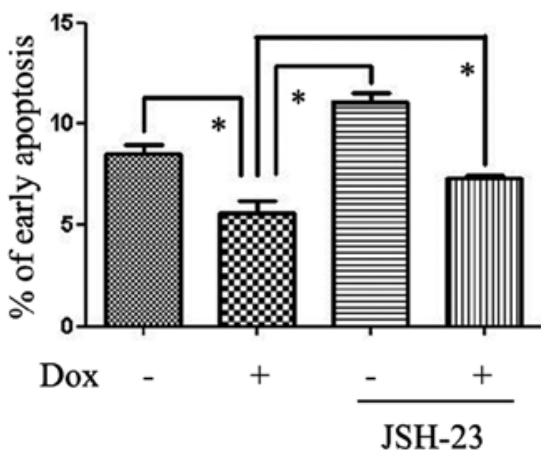

C33A cells

Esposure of $18 \alpha-G A$

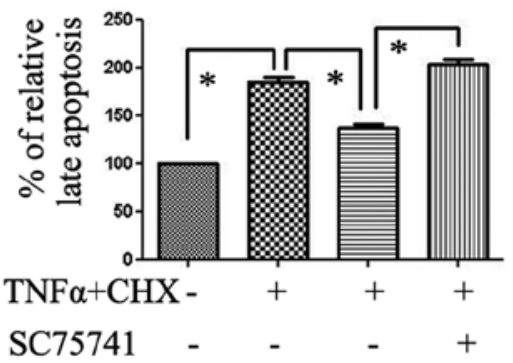

Cx32 siRNA Negative control

Figure 4. Inhibition of NF- $\mathrm{NB}$ supresses the anti-extrinsic apoptotic functions of $\mathrm{Cx} 32$ in cervical cancer cells. (A) To eliminate the interference of tool drugs on apoptosis and to choose suitable drug concentrations, we detected the survival rates of cells using MTT assays. The results showed that the survival rates of the SC75741 $(1 \mu \mathrm{M})$ and JSH-23 $(2 \mu \mathrm{M})$ groups displayed no statistically significant differences compared to those of control group (n=3-4). (B) SC75741, an NF- $\kappa$ B inhibitor, reversed the anti-apoptotic functions of $\mathrm{Cx} 32$ in response to TNF $\alpha(n=3)$. (C) JSH-23, an NF- $\mathrm{B}$ inhibitor, changed the anti-apoptotic functions of $\mathrm{Cx} 32$ ( $\mathrm{n}=3$ ). (D) After treatment with Cx32 siRNA3 to knock down Cx32 expression, all of the groups were incubated with $18 \alpha-\mathrm{GA}$, and some of the groups were incubated with TNF $\alpha+\mathrm{CHX}$ to induce apoptosis in C33A cells. Consistent with the results from the HeLa-Cx32 experiments, the relative apoptosis rates of the Cx32 knockdown groups were much higher than those of the non-specific siRNA groups after cotreatment with TNF $\alpha+\mathrm{CHX}$. SC75741 also inhibited the anti-apoptotic functions of $\mathrm{Cx} 32(\mathrm{n}=3) .{ }^{*} \mathrm{P}<0.05$ with respect to the control or corresponding group.

results were observed for MMP-2, MMP-9 and c-IAP1, which are also $\mathrm{NF}-\kappa \mathrm{B}$ target proteins.

Cx32 exerts an inhibitory effect on extrinsic apoptosis via the NF- $\kappa B$ pathway in CaCx cells. Based on the above results, we next used NF- $\kappa \mathrm{B}$ inhibitors as tools to study the effects of $\mathrm{Cx} 32$. As an inhibitor of NF- $\kappa \mathrm{B}, \mathrm{SC} 75741$ specifically inhibits $\mathrm{NF}-\kappa \mathrm{B}-$ mediated signalling on a transcriptional level (18). Before apoptosis was induced, we added SC75741 or JSH-23 to the cells. We added SC75741 to two of the groups and found that it reduced the anti-apoptotic functions of $\mathrm{Cx} 32$ in response to TNF $\alpha$ (Fig. 4B). Moreover, JSH-23, another NF- $\kappa$ B inhibitor, changed the anti-apoptotic functions of $\mathrm{Cx} 32$ in response to TRAIL when using oleamide $(25 \mu \mathrm{M})$ to inhibit GJs (Fig. 4C). SC75741 also reversed the anti-apoptotic functions of Cx32 in C-33A cells (Fig. 4D). We have summarized the targets of $\mathrm{Cx} 32$ in a diagram to show its functions and downstream signalling pathways (NF- $\mathrm{B}$, c-IAP1, and MMP-2) in the extrinsic apoptotic pathway of $\mathrm{CaCx}$ cells (Fig. 5).

\section{Discussion}

Our data indicate that Cx32, whether in GJs or not, is critical for active $\mathrm{NF}-\kappa \mathrm{B}$ signalling in $\mathrm{CaCx}$ cells. Due to the complexity of GJ-dependent and GJ-independent effects in apoptosis, we focused on the non-junctional functions of $\mathrm{Cx} 32$ in $\mathrm{CaCx}$ in this study. To study these non-junctional functions in apoptosis, 2-APB, 18 $\alpha$-GA, oleamide and lowdensity culturing were utilized to block the effects of GJIC on apoptosis. 


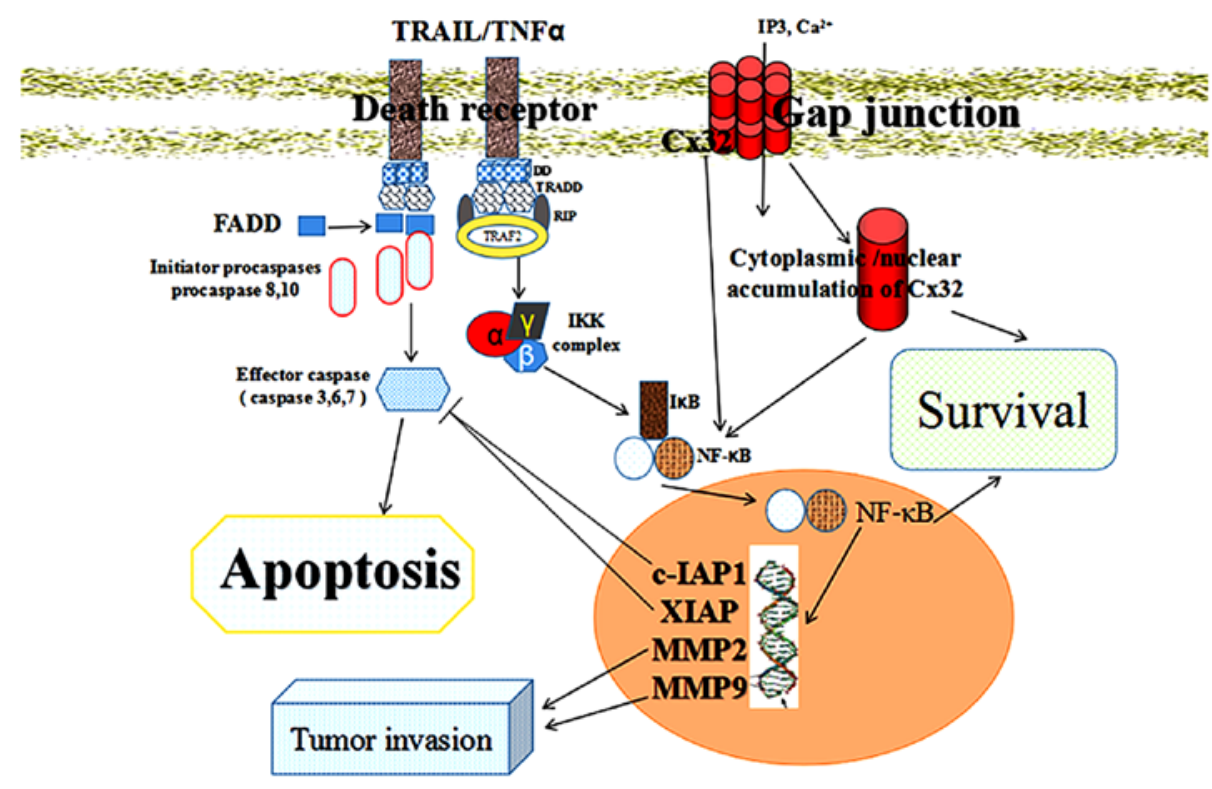

Figure 5. Diagram of the inferred mechanism for Cx32 effects on extrinsic apoptosis. Cx32 suppressed TNF $\alpha$ /TRAIL-induced apoptosis in vitro regardless of whether GJ function was inhibited or was pharmacologically or physically present. Upregulated Cx32 expression and its non-junctional localization in CaCx cells may dominate NF-kB and its downstream targets in cancer cells, thereby producing the anti-extrinsic apoptotic and tumour promoting effects.

There are two major apoptosis pathways, the intrinsic and extrinsic pathways. The extrinsic apoptosis pathway depends on death ligands, which include TNFa, FasL and TRAIL, and their binding to DRs (26). TNF $\alpha$ leads to an increase in apoptosis by upregulating the transcriptional factor FoxO1, which leads to the increased expression of apoptotic genes (27). TNF $\alpha$ can not only induce an inflammatory response but can also induce apoptosis via cotreatment with protein synthesis inhibitors, such as CHX (28). Because the apoptosis rates induced by TNF $\alpha$ were low in our study, we added CHX to promote apoptosis in C33A cells (25). Our data show that TRAIL is a more sensitive cytokine at lower concentrations than TNFa. In fact, TRAIL is a selective cytokine that induces tumour cell apoptosis while sparing normal cells $(29,30)$. To validate the universal functions of $\mathrm{Cx} 32$ in extrinsic apoptosis, we used both TNF $\alpha$ and TRAIL to induce apoptosis in our study.

$\mathrm{CaCx}$ progression is related to EGFR, MMPs and cyclooxygenase-2 (COX-2) overexpression $(31,32)$. TNF $\alpha$-induced NF- $\mathrm{KB}$ activation was not prevented by EGFR or Sre inhibition, suggesting that TNF $\alpha$ exerts both EGFR-dependent and EGFR-independent effects (33). Activation of NF- $\kappa \mathrm{B}$ is a central event in the responses of normal cells to inflammatory signals, such as those caused by HPV infection. Abnormal constitutive activation of NF- $\mathrm{KB}$ is important for the survival of most cancer cells, and the activation of NF- $\mathrm{KB}$ and EGFR can be connected by SOS1 (34). In the apoptosis pathway induced by TNF $\alpha$ or TRAIL, NF- $\mathrm{KB}$ acts as a key factor for cell survival (35). NF-kB, especially the P65 (RelA) subunit, can induce the expression of anti-apoptotic genes, such as IAP genes, thus inhibiting tumour cell apoptosis. XIAP, c-IAP1 and survivin are very important members of the IAP family (36). c-IAP1 and c-IAP2 suppress TNF $\alpha$-stimulated cell death by preventing the formation of the TNF receptor 1 (TNFR1) pro-apoptotic signalling complex (37). Overexpression of XIAP and c-IAP1 are associated with drug resistance in cancer cells and reduce patient survival after chemotherapy and radiotherapy. Our data show that c-IAP1 expression is related to $\mathrm{C} \times 32$ expression. This result demonstrates a relationship between Cx32 and c-IAP1, which may account for the anti-apoptotic effect of $\mathrm{Cx} 32$ in $\mathrm{CaCx}$ cells.

NF- $\mathrm{KB}$ can be activated by many different stimuli including pro-inflammatory cytokines (e.g., TNF $\alpha$, IL-1), lipopolysaccharides, and viral proteins (38). After activation, the transcription factor NF- $\kappa B$ can translocate into the nucleus and bind the promoter of immunoglobulin $\kappa$-chains in B-cells. The downregulation of $\mathrm{Cx} 43$ expression induced by high glucose levels activates NF- $\mathrm{KB}$ in glomerular mesangial cells, leading to renal inflammation (39). Inflammation caused by HPV is an important factor for $\mathrm{CaCx}$ progression. However, whether $\mathrm{Cx} 32$ is related to inflammation requires further study. In our study, we found that high Cx32 expression levels promoted P65 (RelA) expression in the nucleus. After we added SC75741 or JSH-23 to inhibit NF- $\kappa$ B, the anti-apoptotic effects of Cx32 in response to TNF $\alpha$ and TRAIL vanished or weakened. The exact mechanisms for why non-junctional $\mathrm{Cx} 32$ is required in the NF- $\kappa B$ signalling pathway remain unclear.

HPV, like several other viruses, has developed a method for evading the TNF-mediated host immune response (40). One of the key attributes of HPV-induced cervical malignant transformation is HPV E2 gene disruption. E2 may regulate NF- $\mathrm{KB}$ and STAT3 activation in the presence of TNF $\alpha$, with survival implications for HPV-infected cells (41). KIAA1199 is an oncogenic protein induced by HPV infection that connects the NF- $\mathrm{kB}$ and EGFR oncogenic cascades and transmits pro-survival and invasive signals (42). $\mathrm{CaCx}$ cell lines display important differences with respect to Cx32 and HPV. HeLa and $\mathrm{SiHa}$ cells are HPV-positive and $\mathrm{Cx} 32$-negative, while C-33A cells are HPV-negative and Cx32-positive. Therefore, whether HPV and $\mathrm{Cx} 32$ are independent factors in $\mathrm{CaCx}$ could also be a question for further investigation.

The existence of a link between $\mathrm{Cx} 43$ or $\mathrm{Cx} 26$ and MMP expression has been demonstrated in various tumour 
cells $(43,44)$. As a marker for tumour invasion and progression, MMPs are key proteins for the development of tumours and the associated microenvironment (45). In our study, we detected MMP-9 and MMP-2 expression after controlling Cx32 in HeLa-Cx32 cells and found that they had positive correlations with or without TNF $\alpha$ incubation. Perhaps there may be a balance between GJ-associated and non-junctional Cx32 in apoptosis. Thus, the anti- or pro-apoptotic effects of GJs and/or Cx32 play important roles in maintaining this balance depending on their concentration, intensity, or the type of apoptosis inducer. However, although the participation of nuclear Cx proteins in controlling cell- death-related gene expression, partly via Cx-responsive elements (CxRE) has been suggested $(46,47)$, the exact mechanism regarding how $\mathrm{Cx} 32$ modulates $\mathrm{NF}-\kappa \mathrm{B}$ requires further investigation.

In conclusion, by promoting $\mathrm{NF}-\kappa \mathrm{B}$, its downstream signalling pathway components (e.g., c-IAP1, and MMP-2) and aberrant nuclear localization, high $\mathrm{Cx} 32$ expression levels result in anti-apoptotic functions in the extrinsic apoptotic pathway in $\mathrm{CaCx}$, independent of the $\mathrm{Cx} 32$ function in GJs. This study demonstrates that non-junctional $\mathrm{Cx} 32$ serves as a novel regulator of exogenous apoptosis in $\mathrm{CaCx}$ cells, which may provide new insights into the roles of $\mathrm{Cx} 32$ in $\mathrm{CaCx}$ progression and microenvironment formation.

\section{Acknowledgements}

This study was supported in part by the Joint Fund of the National Nature Science Foundation of China (contract no. U1303221), the National Natural Science Foundation of China (contract nos. 81373439 and 81473234), and a grant for the construction of technique plate for evaluation of the pharmacodynamics of new drugs in Xinjiang from the Department of Science and Technology of Guangdong province (contract no. 2014A020209032).

\section{References}

1. Lagunas-Martínez A, Madrid-Marina V and Gariglio P: Modulation of apoptosis by early human papillomavirus proteins in cervical cancer. Biochim Biophys Acta 1805: 6-16, 2010.

2. de Freitas AC, Coimbra EC and Leitão Mda C: Molecular targets of HPV oncoproteins: Potential biomarkers for cervical carcinogenesis. Biochim Biophys Acta 1845: 91-103, 2014.

3. Muench P, Probst S, Schuetz J, Leiprecht N, Busch M, Wesselborg S, Stubenrauch F and Iftner T: Cutaneous papillomavirus E6 proteins must interact with $\mathrm{p} 300$ and block $\mathrm{p} 53$-mediated apoptosis for cellular immortalization and tumorigenesis. Cancer Res 70: 6913-6924, 2010.

4. Parrish AB, Freel CD and Kornbluth S: Cellular mechanisms controlling caspase activation and function. Cold Spring Harb Perspect Biol 5: a8672, 2013.

5. Han J, Soletti RC, Sadarangani A, Sridevi P, Ramirez ME, Eckmann L, Borges HL and Wang JY: Nuclear expression of $\beta$-catenin promotes RB stability and resistance to TNF-induced apoptosis in colon cancer cells. Mol Cancer Res 11: 207-218, 2013.

6. Carette D, Gilleron J, Chevallier D, Segretain D and Pointis G: Connexin a check-point component of cell apoptosis in normal and physiopathological conditions. Biochimie 101: 1-9, 2014

7. Kameritsch P, Khandoga N, Pohl U and Pogoda K: Gap junctional communication promotes apoptosis in a connexintype-dependent manner. Cell Death Dis 4: e584, 2013.

8. Mao XY, Li QQ, Gao YF, Zhou HH, Liu ZQ and Jin WL: Gap junction as an intercellular glue: Emerging roles in cancer EMT and metastasis. Cancer Lett 381: 133-137, 2016.
9. Zhao B, Zhao W, Wang Y, Xu Y, Xu J, Tang K, Zhang S, Yin Z, Wu Q and Wang X: Connexin32 regulates hepatoma cell metastasis and proliferation via the p53 and Akt pathways. Oncotarget 6: 10116-10133, 2015.

10. Chen ZY, Wang R, Huang F, Yuan DD and Li SR: Inhibition of gap junctions relieves the hepatotoxicity of TNF- $\alpha$. Genet Mol Res 14: 11896-11904, 2015.

11. Zhao Y, de Toledo SM, Hu G, Hei TK and Azzam EI: Connexins and cyclooxygenase- 2 crosstalk in the expression of radiationinduced bystander effects. Br J Cancer 111: 125-131, 2014.

12. Autsavapromporn N, De Toledo SM, Jay-Gerin JP, Harris AL and Azzam EI: Human cell responses to ionizing radiation are differentially affected by the expressed connexins. J Radiat Res (Tokyo) 54: 251-259, 2013.

13. Murphy SF, Varghese RT, Lamouille S, Guo S, Pridham KJ, Kanabur P, Osimani AM, Sharma S, Jourdan J, Rodgers CM, et al: Connexin 43 inhibition sensitizes chemoresistant glioblastoma cells to temozolomide. Cancer Res 76: 139-149, 2016.

14. Kim YJ, Kim J, Kim YS, Shin B, Choo OS, Lee JJ and Choung YH: Connexin 43 acts as a proapoptotic modulator in cisplatin-induced auditory cell death. Antioxid Redox Signal 25: 623-636, 2016.

15. Cao YW, Lu TC, Pan XL, Li F, Zhong HH, Sun Y, Jiang JF and Li L: Correlation of expression of connexin to growth and progression of cervical carcinoma in situ. Chin J Cancer 24: 567-572, 2005 (In Chinese).

16. Aasen T, Graham SV, Edward M and Hodgins MB: Reduced expression of multiple gap junction proteins is a feature of cervical dysplasia. Mol Cancer 4: 31, 2005.

17. Zhao Y, Lai Y, Ge H, Guo Y, Feng X, Song J, Wang Q, Fan L, Peng Y, Cao M, et al: Non-junctional Cx32 mediates anti-apoptotic and pro-tumor effects via epidermal growth factor receptor in human cervical cancer cells. Cell Death Dis 8: e2773, 2017.

18. Ehrhardt C, Rückle A, Hrincius ER, Haasbach E, Anhlan D, Ahmann K, Banning C, Reiling SJ, Kühn J, Strobl S, et al: The NF- $\kappa$ B inhibitor SC75741 efficiently blocks influenza virus propagation and confers a high barrier for development of viral resistance. Cell Microbiol 15: 1198-1211, 2013.

19. Wu D, Fan L, Xu C, Liu Z, Zhang Y, Liu L, Wang Q and Tao L: GJIC Enhances the phototoxicity of photofrin-mediated photodynamic treatment by the mechanisms related with ROS and Calcium pathways. J Biophotonics 8: 764-774, 2015.

20. Goldberg GS, Bechberger JF and Naus CC: A pre-loading method of evaluating gap junctional communication by fluorescent dye transfer. Biotechniques 18: 490-497, 1995.

21. Zhu M, Du J, Liu AD, Holmberg L, Chen SY, Bu D, Tang C and Jin H: L-cystathionine inhibits oxidized low density lipoproteininduced THP-1-derived macrophage inflammatory cytokine monocyte chemoattractant protein-1 generation via the NF- $\kappa \mathrm{B}$ pathway. Sci Rep 5: 10453, 2015

22. Juszczak GR and Swiergiel AH: Properties of gap junction blockers and their behavioural, cognitive and electrophysiological effects: Animal and human studies. Prog Neuropsychopharmacol Biol Psychiatry 33: 181-198, 2009.

23. Yang Y, Qin SK, Wu Q, Wang ZS, Zheng RS, Tong XH, Liu H, Tao L and He XD: Connexin-dependent gap junction enhancement is involved in the synergistic effect of sorafenib and all-trans retinoic acid on HCC growth inhibition. Oncol Rep 31: 540-550, 2014.

24. He B, Tong X, Wang L, Wang Q, Ye H, Liu B, Hong X, Tao L and Harris AL: Tramadol and flurbiprofen depress the cytotoxicity of cisplatin via their effects on gap junctions. Clin Cancer Res 15: 5803-5810, 2009.

25. Qi Z, Shen L, Zhou H, Jiang Y, Lan L, Luo L and Yin Z: Phosphorylation of heat shock protein 27 antagonizes TNF- $\alpha$ induced HeLa cell apoptosis via regulating TAK1 ubiquitination and activation of p38 and ERK signaling. Cell Signal 26: 1616-1625, 2014

26. Dai X, Zhang J, Arfuso F, Chinnathambi A, Zayed ME, Alharbi SA, Kumar AP, Ahn KS and Sethi G: Targeting TNF-related apoptosis-inducing ligand (TRAIL) receptor by natural products as a potential therapeutic approach for cancer therapy. Exp Biol Med (Maywood) 240: 760-773, 2015.

27. Zhang B, Gui L, Zhu L, Zhao X, Yang Y and Li Q: Forkhead box protein $\mathrm{O} 1$ mediates apoptosis in a cancer cervical cell line treated with the antitumor agent tumor necrosis factor- $\alpha$. Genet Mol Res 14: 7446-7454, 2015.

28. Wang L, Du F and Wang X: TNF-alpha induces two distinct caspase-8 activation pathways. Cell 133: 693-703, 2008

29. Oikonomou E and Pintzas A: The TRAIL of oncogenes to apoptosis. Biofactors 39: 343-354, 2013. 
30. Sadarangani A, Kato S, Espinoza N, Lange S, Llados C, Espinosa M, Villalón M, Lipkowitz S, Cuello M and Owen GI: TRAIL mediates apoptosis in cancerous but not normal primary cultured cells of the human reproductive tract. Apoptosis 12: 73-85, 2007.

31. Bauvois B: New facets of matrix metalloproteinases MMP-2 and MMP-9 as cell surface transducers: Outside-in signaling and relationship to tumor progression. Biochim Biophys Acta 1825 29-36, 2012.

32. Soonthornthum T, Arias-Pulido H, Joste N, Lomo L, Muller C, Rutledge $\mathrm{T}$ and Verschraegen $\mathrm{C}$ : Epidermal growth factor receptor as a biomarker for cervical cancer. Ann Oncol 22: 2166-2178, 2011.

33. Kakiashvili E, Dan Q, Vandermeer M, Zhang Y, Waheed F, Pham $\mathrm{M}$ and Szászi K: The epidermal growth factor receptor mediates tumor necrosis factor-alpha-induced activation of the ERK/ GEF-H1/RhoA pathway in tubular epithelium. J Biol Chem 286: 9268-9279, 2011.

34. De S, Dermawan JK and Stark GR: EGF receptor uses SOS1 to drive constitutive activation of NFKB in cancer cells. Proc Nat Acad Sci USA 111: 11721-11726, 2014.

35. Flusberg DA and Sorger PK: Surviving apoptosis: Life-death signaling in single cells. Trends Cell Biol 25: 446-458, 2015.

36. Yi XP, Han T, Li YX, Long XY and Li WZ: Simultaneous silencing of XIAP and survivin causes partial mesenchymalepithelial transition of human pancreatic cancer cells via the PTEN/PI3K/Akt pathway. Mol Med Rep 12: 601-608, 2015.

37. Varfolomeev E and Vucic D: (Un)expected roles of c-IAPs in apoptotic and NFkappaB signaling pathways. Cell Cycle 7: $1511-1521,2008$

38. Sethi G, Shanmugam MK, Ramachandran L, Kumar AP and Tergaonkar V: Multifaceted link between cancer and inflammation. Biosci Rep 32: 1-15, 2012

39. Xie X, Lan T, Chang X, Huang K, Huang J, Wang S, Chen CX, Liu $\mathrm{P}$ and Huang $\mathrm{H}$ : Connexin 43 mediates $\mathrm{NF}-\kappa \mathrm{B}$ signalling activation induced by high glucose in GMCs: Involvement of c-Src. Cell Commun Signal 11: 38, 2013.
40. Filippova M, Song H, Connolly JL, Dermody TS and DuerksenHughes PJ: The human papillomavirus 16 E6 protein binds to tumor necrosis factor (TNF) R1 and protects cells from TNF-induced apoptosis. J Biol Chem 277: 21730-21739, 2002.

41. Prabhavathy D, Prabhakar BN and Karunagaran D: HPV16 E2-mediated potentiation of $\mathrm{NF}-\kappa \mathrm{B}$ activation induced by TNF- $\alpha$ involves parallel activation of STAT3 with a reduction in E2-induced apoptosis. Mol Cell Biochem 394: 77-90, 2014.

42. Shostak K, Zhang X, Hubert P, Göktuna SI, Jiang Z, Klevernic I, Hildebrand J, Roncarati P, Hennuy B, Ladang A, et al: NF- $\kappa$ B-induced KIAA1199 promotes survival through EGFR signalling. Nat Commun 5: 5232, 2014.

43. Yano T and Yamasaki H: Regulation of cellular invasion and matrix metalloproteinase activity in HepG2 cell by connexin 26 transfection. Mol Carcinog 31: 101-109, 2001.

44. Lamiche C, Clarhaut J, Strale PO, Crespin S, Pedretti N, Bernard FX, Naus CC, Chen VC, Foster LJ, Defamie N, et al: The gap junction protein $\mathrm{Cx} 43$ is involved in the bone-targeted metastatic behaviour of human prostate cancer cells. Clin Exp Metastasis 29: 111-122, 2012.

45. Kessenbrock K, Plaks V and Werb Z: Matrix metalloproteinases: Regulators of the tumor microenvironment. Cell 141: 52-67, 2010.

46. Kardami E, Dang X, Iacobas DA, Nickel BE, Jeyaraman M, Srisakuldee W, Makazan J, Tanguy S and Spray DC: The role of connexins in controlling cell growth and gene expression. Prog Biophys Mol Biol 94: 245-264, 2007.

47. Decrock E, Vinken M, De Vuyst E, Krysko DV, D'Herde K, Vanhaecke T, Vandenabeele P, Rogiers V and Leybaert L: Connexin-related signaling in cell death: To live or let die? Cell Death Differ 16: 524-536, 2009. 